\title{
ANALISIS KELAYAKAN INTRODUKSI TANAM GANDA (DOUBLE RAW) UBI KAYU PADA USAHATANI SISTEM TUMPANGSARI DI LAHAN KERING DI KABUPATEN GUNUNGKIDUL
}

\author{
Subagiyo dan Charisnalia \\ Balai Pengkajian Teknologi Pertanian Yogyakarta \\ Jl. Stadion Maguwoharjo No. 22, Wedomartani, Ngemplak, Sleman, Yogyakarta \\ E-mail: subagiyosarbini@yahoo.com
}

\begin{abstract}
ABSTRAK
Penelitian ini bertujuan untuk menganalisis kelayakan introduksi tanam ganda (double raw) ubi kayu pada system tumpangsari di lahan kering Kabupaten Gunungkidul. Penelitian dilaksanakan pada bulan Januari sampai dengan bulan Oktober 2016 di Desa Namberan, Paliyan, Kabupaten Gunungkidul. Metodelogi yang digunakan dengan pendekatan on partisipatif farm research dan survai, dengan jumlah responden 30 orang. Data yang terkumpul selanjutnya dianalisis menggunakan pendekatan analisis Marginal Benefit Cost Ratio (MBCR). Hasil Penelitian menunjukkan bahwa introduksi tanam ganda ubi kayu pada sistem tumpangsari yang biasa dilakukan oleh para petani kabupaten Gunungkidul yaitu tanaman ubi kayu ditanam di awal musim hujan sekaligus menanam padi, setelah padi dipanen disusul dengan tanaman kacang tanah disisipi dengan tanaman jagung. Sedangkan ubi kayu di panen paling akhir, dengan system tumpangsari ini petani dalam satu tahun panen 3 kali yaitu padi, jagung kacang tanah dan ubi kayu. Berdasarkan analisis kelayakan introduksi tanam ganda pada usahatani dengan sistem tumpangsari memberikan tambahan pendapatan dalam satu tahun sebesar Rp 1.530.700 dengan nilai MBCR ratio sebesar 2,33 .
\end{abstract}

Kata kunci: Usahatani, tumpangsari, lahan kering.

\begin{abstract}
This study aims to analyze the feasibility of the introduction of double planting of cassava in the intercropping system in dry land of Gunungkidul Regency. The study was conducted from January to October 2016 in Namberan Village, Paliyan, Gunungkidul Regency. Methodology used with participatory approach on farm research and survey, with 20 respondents. The collected data is then analyzed using Marginal Benefit Cost Ratio (MBCR) analysis approach. The results showed that the introduction of double cassava planting in the intercropping system commonly done by the farmers of Gunungkidul district that is cassava planted at the beginning of the rainy season as well as planting rice, after harvested rice followed by peanut crops inserted with corn crops. While the cassava in the last harvest, with this intercropping system farmers in one year harvest 3 times that of rice, corn peanuts and cassava. Based on the analysis of the feasibility of introduction of double cropping in farming with intercropping system gives additional income in one year amounting to Rp $1,530,700$ with $M B C R$ ratio value equal to 2,33.
\end{abstract}

Keywords: Farming, intercropping, dry land

\section{PENDAHULUAN}

Ubi kayu (Manihot esculenta crantz), merupakan komoditas tanaman pangan penting di Indonesia setelah padi, jagung, kedelai, kacang tanah dan kacang hijau. Selain sebagai bahan pangan, ubi kayu juga banyak dipakai untuk bahan pakan, bahan baku industri serta bahan baku bioetanol. Sejalan dengan program diversifikasi pangan, permintaan ubi kayu terus meningkat setiap tahunnya dan menyerap 62-78
$\%$ dari produksi nasional, akibatnya ketersediaan ubi kayu segar untuk bahan baku industri semakin berkurang. Dirjentan (2014) menyebutkan, berdasarkan hasil susenas BPS 2010 kebutuhan ubi kayu untuk bahan baku industri laju pertumbuhannya meningkat ratarata 6,33\%. Pada tahun 2013, ekspor ubi kayu nasional bentuk gaplek sebesar 185.679 ton atau setara dengan 516 ribu ton ubi kayu segar, meningkat $278 \%$ dibanding tahun 2012 sebesar 
47.890 ton gaplek, setara 133 ribu ubi kayu segar. Impor sebesar 220.189 gaplek, setara 600 ribu ton ubi kayu segar menurun sebesar $75 \%$, dibanding tahun 2012 sebesar 771 ribu ton gaplek atau setara dengan 2,1 juta ton ubi kayu segar.

Dalam upaya mendukung peningkatan produksi ubi kayu nasional, Kementerian Pertanian memasukkan ubi kayu sebagai jenis komoditas tanaman binaan yang tertuang dalam Keputusan Menteri Pertanian Nomor 511 Tahun 2006 tanggal 12 September 2006 tentang Jenis Komoditi Tanaman Binaan Direktorat Jenderal Perkebunan, Direktorat Jenderal Tanaman Pangan dan Direktorat Jenderal Hortikultura (Dirjentan, 2014). Selain itu, pada tahun 2013 Kementerian pertanian melalui Jenderal Tanaman Pangan juga telah menyusun program upaya peningkatan produktivitas ubi kayu melalui bantuan paket teknologi pengembangan ubi kayu yang telah berjalan selama 4 tahun (Dirjentan, 2013). Mengingat berbagai fungsi dan besarnya kebutuhan akan ubi kayu, pada tahun 2015 Kementerian Pertanian kembali mengeluarkan Surat Keputusan Menteri Pertanian Nomor : 03/Kpts/PD.120/1/2015 tanggal 2 Januari 2015 tentang Penetapan Kawasan Padi, Jagung, Kedelai dan Ubi kayu Nasional. Dengan dikeluarkannya surat keputusan tersebut, diharapkan komoditas ubi kayu dengan Gunungkidul sebagai kawasannya mampu berkontribusi dalam upaya pengembangan kawasan tanaman pangan nasional.

Ubi kayu di wilayah gunungkidul ditanam dengan pola tumpangsari dengan tanaman pangan lain seperti padi, jagung dan kacang tanah. Menurut Wijanarko, dkk (2011), tumpangsari ubi kayu dengan kacang tanah memiliki beberapa keuntungan, diantaranya: (1) Meningkat kan C-organik tanah, dan memperbaiki sifat kimia tanah lainnya, (2) Tanaman kacang-kacangan dapat menyumbangkan sekitar $30 \% \mathrm{~N}$ hasil dari proses fiksasi $\mathrm{N}$ kepada tanaman lainnya dalam sistem tumpangsari maupun rotasi. Tambahan dari residu akar tanaman legume sekitar $5-15 \mathrm{~kg}$ N/ha, (3) Menurunkan erosi sekitar 48\% dan hasil umbi $20 \%$ lebih tinggi dibandingkan dengan hasil ubikayu monokultur, (4) Meningkatkan efisiensi penggunaan lahan dan pendapatan petani, (5) Menjamin ketersediaan pakan ternak dan (6) Menjamin kelestarian lahan dan stabilitas hasil. Penelitian ini bertujuan untuk mengetahui kelayakan introduksi tanam ganda (double raw) pada usahatani sistem tumpangsari di lahan kering di Kabupaten Gunungkidul Daerah Istimewa Yogyakarta.

\section{METODOLOGI}

Penelitian dilaksanakan di Desa

Karangasem, Paliyan, Kabupaten Gunungkidul

Daerah Istimewa Yogykarta (DIY) yang merupakan lokasi kegiatan introduksi tanam ganda pada usahatani system tumpangsari di Gunungkidul. Penelitian dilaksanakan pada bulan September 2015 - Agustus 2016. Pelaksanaan pengkajian dengan menggunakan pendekatan on farm research dan survai dengan pendekatan kualitatif dan kuantitatif. Data primer diperoleh langsung dari responden, informan dan hasil pengamatan. Responden dalam penelitian ini adalah para petani tanaman tumpangsari dengan jumlah 20 responden. Kelayakan finansial menggunakan analisis Marginal Benefit Cost Ratio (MBCR). Rumus Marginal Benefit Cost Ratio (MBCR) menurut Malian (2004) adalah sebagai berikut:

$$
M B C R=\frac{\text { Penerimaan }(B)-\text { Penerimaan }(P)}{\text { Total Biaya }(B)-\text { Total Biaya }(P)}
$$

dimana :

$\mathrm{B}=$ Teknologi baru (introduksi)

$\mathrm{P}=$ Teknologi Petani (existing)

\section{HASIL DAN PEMBAHASAN}

Karakteristik Petani. Survey petani

responden dilakukan untuk mengetahui karakteristik petani yang meliputi umur, tingkat pendidikan, tanggungan keluarga, luas lahan, pengalaman bertani dan pengalaman mengikuti pelatihan. Adapun karekateristik responden secara berurutan disajikan sebagai berikut :

Umur responden. Umur petani berkaitan erat dengan kemampuan fisik dalam mengelola usahatani. Seeorang yang masih muda beraktivitas cenderung lebih mampu secara fisik, dan sebaliknya semakin tua usia seseorang kemampuan fisiknya akan berkurang. Sebaran umur petani kooperator pengkajian inovasi teknologi ubi kayu tanam baris ganda pada sistem tumpangsari disajikan pada gambar 1 . Umur petani sebagian $(43 \%)$ berada pada usia 33 - 43. Petani dengan usia ini masih dinilai produktif, sehingga lebih bisa menerima adanya inovasi dibandingkan petani usia tua.

Tingkat pendidikan responden. Tingkat pendidikan formal petani kooperator di Kecamatan Paliyan ditunjukkan pada gaambar 
2. Sebagian besar petani memiliki tingkat pendidikan rendah yakni tidak lulus SD (73\%). Selain itu petani yang memiliki tingkat pendidikan SLTP sebesar $18 \%$, sedangkan yang berpendidikan lulus SLTA hanya $9 \%$. Tinggi rendahnya tingkat pendidikan sangat menentukan kemampuan petani dalam menerima suatu inovasi.

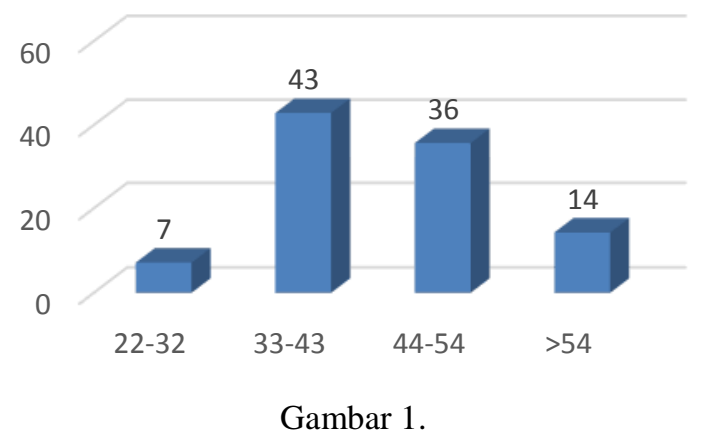

Sebaran petani berdasarkan kelompok umur.

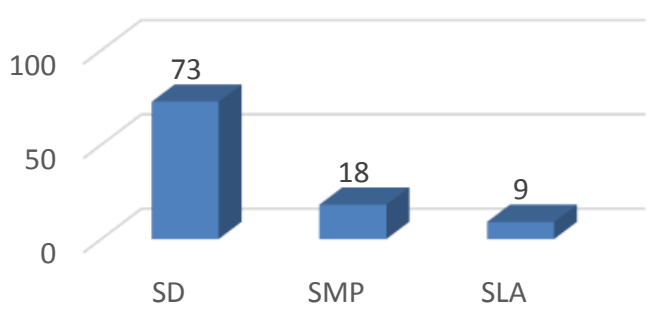

Gambar 2.

Sebaran petani berdasarkan tingkat pendidikan.

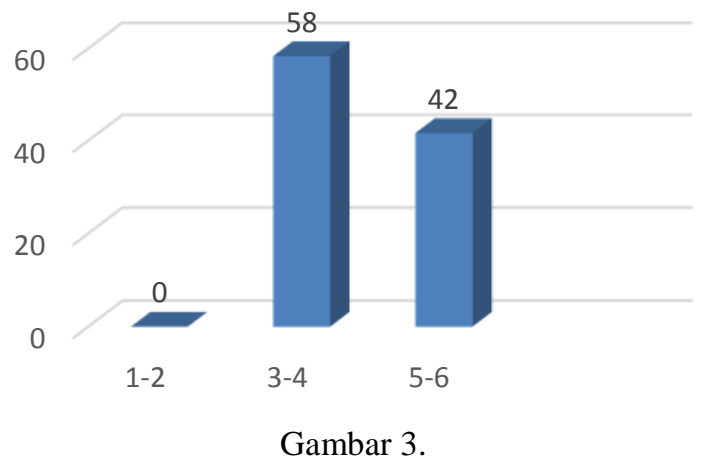

Sebaran petani berdasarkan jumlah tanggungan keluarga.

Tanggungan keluarga. Jumlah tanggungan keluarga petani kooperator pengkajian ditunjukkan pada gambar 3 . Sejumlah $58 \%$ petani kooperator memiliki tanggungan keluarga 3-4 orang, sedangkan sisanya $42 \%$ memiliki tanggungan keluarga 5-6 orang. Banyaknya jumlah tanggungan keluarga yang dimiliki, sedikit banyak akan ikut mempengaruhi tingkat kesejahteraan petani apabila dikorelasikan dengan jumlah pendapatan yang diperoleh.

Luas lahan. Gambar 4 menunjukkan bahwa sebagian besar petani kooperator (73\%) memiliki luas lahan $500-1500 \mathrm{~m}^{2}$. Sedangkan sisanya memiliki luas lahan $3000-4002 \mathrm{~m}^{2}$ (9\%), 4003-5003 $\mathrm{m}^{2}(9 \%)$ dan $>5000 \mathrm{~m}^{2}$ sejumlah $9 \%$. Luas lahan yang dimiliki petani akan mempengaruhi besar kecilnya pendapatan petani.

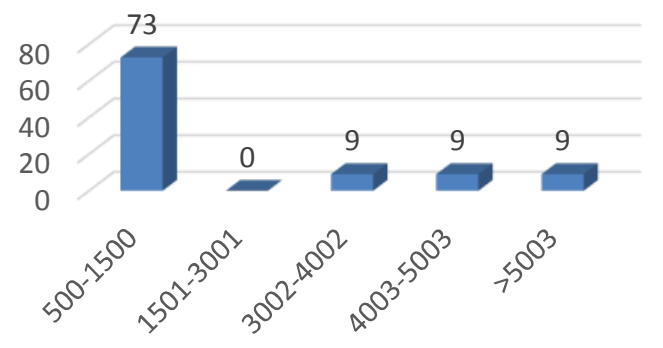

Gambar 4.

Sebaran petani berdasarkan luas kepemilikan lahan.

Pengalaman Bertani. Gambar 5 menunjukkan lamanya pengalaman bertani petani kooperator. Sebanyak $57 \%$ petani kooperator memiliki pengalaman bertani 11-21 tahun. Lamanya pengalaman bertani mempengaruhi banyak sedikitnyanya pengalaman/ilmu yang dimiliki seorang petani dalam budidaya ubi kayu. Dari pengalaman ini mereka akan belajar berbagai disiplin ilmu secara informal, sehingga akan mempengaruhi cara budidaya yang mereka terapkan.

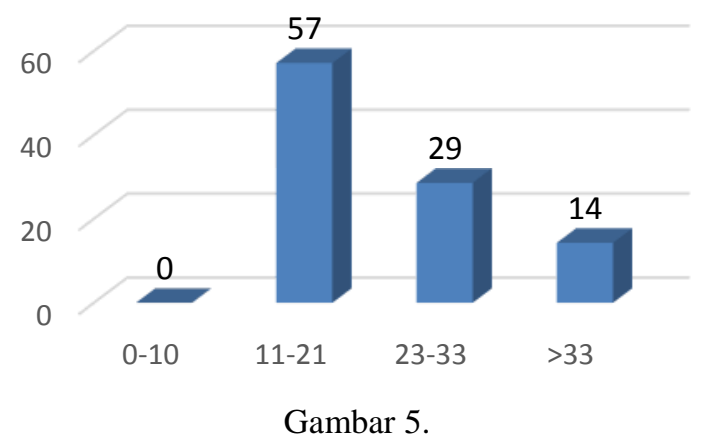

Sebaran petani berdasarkan pengalaman bertani.

Keragaan introduksi tanam ganda. Pengkajian inovasi teknologi ubi kayu tanam baris ganda pada sistem tumpangsari tanaman pangan di lahan kering dilaksanakan dengan melibatkan 20 petani kooperator yang lahannya digunakan sebagai demplot. Luas demplot pengkajian $\pm 1,5$ hektar yang terbagi menjadi 4 
(empat) lokasi, yaitu lokasi Sodong, Semuten, Kenteng I dan Kenteng II. Penerapan paket teknologi yang dikaji melalui percobaan di lapangan dengan menggunakan hamparan lahan kelompok tani kooperator dengan luas hamparan kurang lebih 1,5 ha. Perlakuan yang akan dilakukan terdiri dari 5 perlakuan yang akan diulang 4 kali.

Sedangkan pengamatan yang dilakukan meliputi karakteristik agronomi dan produktivitas:

\section{Karakteristik agronomi}

Tinggi Tanaman. Berdasarkan hasil analisa tinggi tanaman menunjukkan tidak berbeda nyata pada seluruh perlakuan. Meski demikian pada perlakuan paket teknologi 1 dan 2 , yaitu pada perlakuan tanam baris ganda terlihat tinggi tanaman lebih dari pada yang lain. Hal ini disebabkan pada perlakuan tanam baris ganda tanaman lebih rapat sehingga terjadi saling menaungi yang menyebabkan cahaya matahari tidak dapat masuk ke sela-sela tanaman secara sempurna. Hal ini menyebabkan terjadinya etiolase. Sesuai dengan pendapat Turmuktini (2012), kompetisi tanaman untuk mendapatkan sinar matahari semakin tinggi pada kerapatan tanaman yang padat dibandingkan dengan kerapatan tanaman yang lebih renggang, hal ini berakibat berakibat tanaman saling menaungi sehingga tampilan tanaman menjadi lebih tinggi karena tanaman kekurangan cahaya yang menyebabkan terjadi etiolasi yang menyebabkan tinggi tanaman menjadi lebih tinggi.

Jumlah Daun. Berdasarkan hasil analisa jumlah daun menunjukkan tidak berbeda nyata pada seluruh perlakuan. Hal ini menunjukkan adanya berbagai perlakuan tidak mempengaruhi banyaknya jumlah daun. Apabila dilihat dari pengamatan sampai dengan tanaman ubi kayu umur 6 bulan, terjadi peningkatan jumlah daun. Hal ini menunjukkan kemampuan tanaman ubi kayu dalam memanfaatkan faktor tumbuh yang tersedia untuk fotosintesis. Akan tetapi, kebiasaan dan frekuensi petani dalam melakukan perompesan daun untuk pakan ternak juga akan sangat mempengaruhi jumlah daun yang tersisa pada tanaman ubi kayu selain daun yang mati karena tua. Selain itu, tidak berbeda nyata pada jumlah daun juga dimungkinkan karena kedua varietas ubi kayu yang digunakan memiliki potensi hasil secara genetik sama. Sesuai dengan pendapat Bahri dan Santoso (2013), perbedaan yang tidak nyata jumlah daun antar varietas lokal dan unggul disebabkan oleh potensi hasil kedua varietas tersebut yang memang secara genetik homogen.

Diameter Batang. Berdasarkan hasil analisa diameter batang menunjukkan tidak berbeda nyata pada seluruh perlakuan. Hal ini dimungkinkan kedua varietas ubi kayu tersebut merupakan tanaman yang telah ditanam selama bertahun tahun oleh masyarakat lokasi pengkajian, sehingga keduanya telah mampu beradaptasi dengan lingkungan. Varietas ubi kayu yang telah beradaptasi dengan lingkungan akan mampu mengembangkan seluruh komponen sel dan fungsi tanaman berupa akar dan daun secara sempurna. Komponen tanaman yang telah berkembang secara sempurna akan mampu memanfaatkan faktor tumbuh untuk pertumbuhannya. Menurut Widiyastiningsih et al. (2012) pertambahan ukuran tubuh tanaman diakibatkan pertambahan jaringan sel yang dihasilkan oleh pertambahan ukuran sel.

Jumlah Umbi. Berdasarkan hasil analisa jumlah umbi menunjukkan tidak berbeda nyata pada seluruh perlakuan. Hal tersebut menunjukkan kedua varietas tersebut secara genetik memiliki potensi hasil yang sama. Apabila kita cermati lebih lanjut, pada hasil analisa terlihat ubi kayu yang ditanam dengan sistem baris ganda memiliki jumlah umbi yang lebih sedikit jika dibandingkan dengan perlakuan yang lain.

Berat Umbi. Berdasarkan hasil analisa berat umbi menunjukkan tidak berbeda nyata pada seluruh perlakuan. Pemilihan varietas menentukan dalam produksi per satuan luas. Selain itu pemilihan stek ubi kayu yang berkualitas juga berpengaruh pada hasil. Bibit ubikayu yang berkualitas merupakan modal utama dalam meningkatkan produksi (Balitbangtan, 2011). Pada saat pelaksanaan pengkajian bibit ubi kayu yang bersertifikat sulit diperoleh karena musim kering yang panjang pada tahun sebelumnya. Sehingga stek ubi kayu harus mencari ke berbagai daerah di gunungkidul. Menurut Restiani et al. (2014) dalam Rahman, dkk (2015), asal stek, diameter bibit, ukuran stek, dan lama penyimpanan bibit berpengaruh terhadap daya tumbuh dan produksi ubi kayu.

Adanya pengaruh gangguan hama kera dan intensitas hujan yang tinggi selama pengkajian turut mempengaruhi umbi yang dihasilkan. Faktor-faktor lingkungan akan mempengaruhi pertumbuhan dan perkembangan tanaman. Keragaman di dalam faktor lingkungan mempengaruhi tanggapan tanaman 
pada berbagai tingkatan pertumbuhan yang pada akhirnya mempengaruhi hasil tanaman (fitriani dkk, 2015).

Produktivitas Ubi Kayu. Berdasarkan analisa parameter ubi kayu pada demplot pengkajian, diketahui produktivitas ubi kayu sebagai berikut :

Tabel 1.

Produktivitas Ubi Kayu.

\begin{tabular}{lcc}
\hline Perlakuan & $\begin{array}{l}\text { Jumlah tana- } \\
\text { man perhektar }\end{array}$ & $\begin{array}{c}\text { Produksi per } \\
\text { hektar (ton/ha) }\end{array}$ \\
\hline Paket Perlakuan I & 9000 & 36.93 \\
Paket Perlakuan II & 9000 & 32.79 \\
Paket Perlakuan III & 5000 & 21.33 \\
Paket Perlakuan IV & 5000 & 26.43 \\
Kebiasaan Petani & 5000 & 24.9 \\
\hline
\end{tabular}

Teknik budidaya ubi kayu tanam baris ganda akan meningkatkan produksi $31,69 \%$ $48,32 \%$ yang disebabkan penambahan populasi tanaman per hektar jika dibandingkan dengan teknik budidaya cara petani.

Analisis Kelayakan Finansial. Untuk keperluan analisis kelayakan introduksi tanam ganda ubi kayu pada system tumpangsari, dilakukan dengan cara menghitung semua komponen biaya yang dikeluarkan untuk usahatani system tumpangsari dengan mebandingkan teknologi yang dilakukan oleh petani. Dengan membandingkan kedua teknologi tersebut maka akan diketahui keuntungan dan kerugian dari masing-masing teknologi tersebut. Berdasarkan hasil analisis maka introdusi teknologi tanam ganda (double

Tabel 2.

Analisis Input Output Introduksi teknologi tanaman ganda (double row) pada usahatani system tumpangsari.

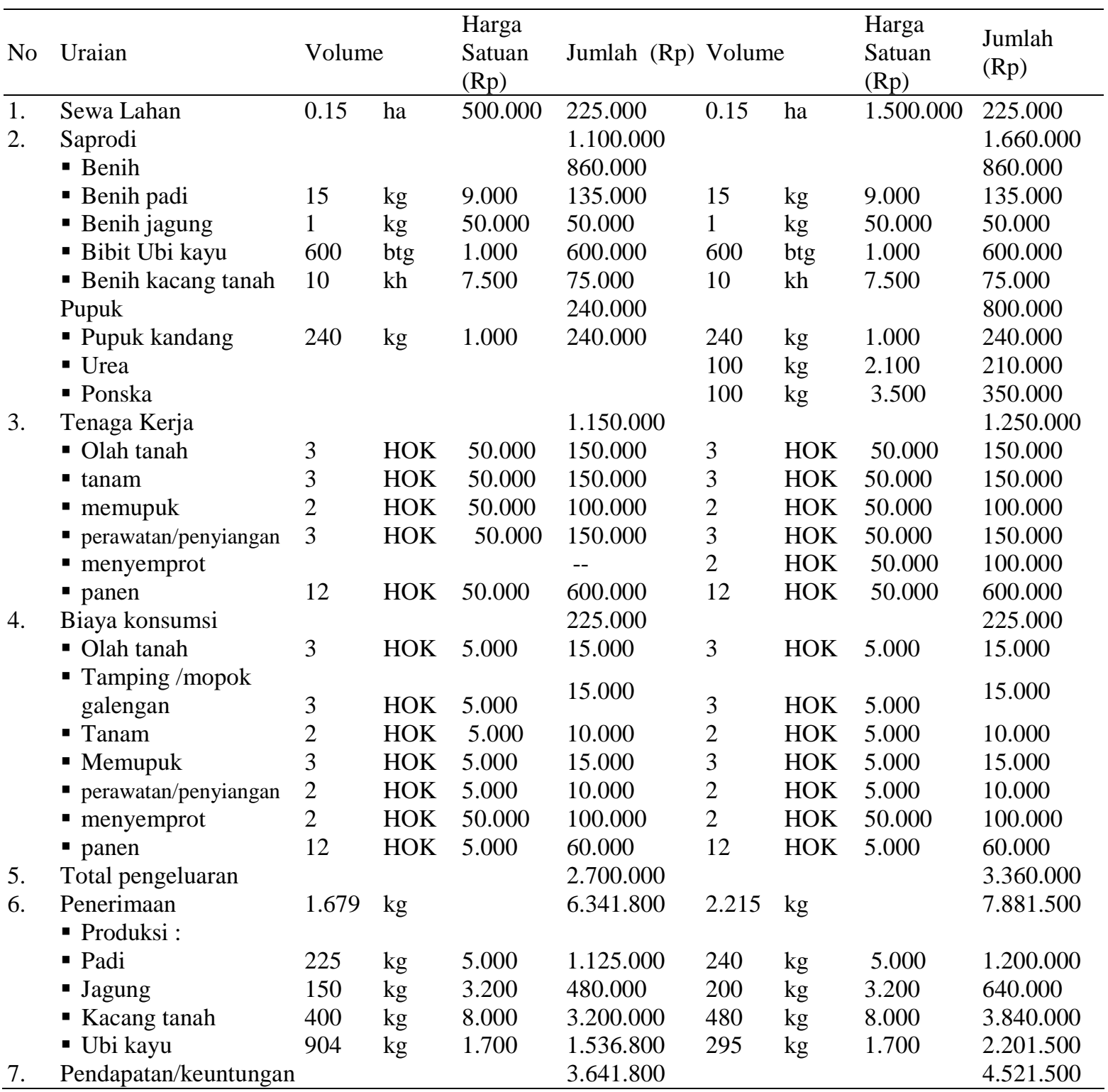


Tabel 3 .

Analisis Partial Perubahan Introduksi teknologi tanam berganda (double raw) pada sisitem tanaman tumpangsari

\begin{tabular}{lcll}
\hline Losses (korbanan) & Jumlah & Gains (tambahan) & Jumlah \\
\hline Tambahan biaya saprodi & 560,000 & $\begin{array}{l}\text { Tambahan Penerimaan dari kenaikan } \\
\text { produksi } 536 \mathrm{~kg}\end{array}$ & $1,539,700$ \\
Tambahan baiya tenaga kerja & 100,000 & & \\
\hline Total losses & & & $1,539,700$ \\
\hline
\end{tabular}

Tanbahan Keuntungan $=1.539 .700-660.000=879.700 ; \mathrm{MBCR}=2,33$

raw) pada usahatani system tumpangsari dapat memberikan keuntungnan bagi petani. Introduksi teknologi tanam ganda (double raw) pada usahatani system tumpangsari memberikan selisih keuntungan sebesar $\mathrm{Rp}$ 879,700 dengan nilai MBCR sebesar 2,33 yang berarti bahwa setiap penambahan biaya sebesar satu satuan akan menghasilkan tambahan pendapatan sebesar 2,33 satuan. Berdasarkan hasil perhitungan tersebut memberi gambaran bahwa introduksi teknologi tersebut layak secara finansial. Untuk lebih jelasnya, maka perhitungan analisis kelayakan finansial introduksi teknologi tanam ganda (double row) pada usahatani sistem tumpangsari disajikan pada Tebel 2.

\section{KESIMPULAN}

Introduksi teknologi tanam ganda (double raw) pada usahatani system tumpangsari mampu meningkatkan produksi $536 \mathrm{~kg}$ dengan luas lahan $1.500 \mathrm{~m}^{2}$ lebih tinggi dibandingkan dengan teknologi yang biasa dilakukan oleh petani. Introduksi teknologi tanam ganda (double raw) di desa Karangasem Kecamatan Paliyan, Kabupaten Gunungkidul memberikan selisih keuntungan sebesar Rp 879.700 dengan nilai MBCR sebesar 2,33 yang berarti bahwa setiap penambahan biaya sebesar satu satuan akan menghasilkan tambahan pendapatan sebesar 2,33 satuan. Berdasarkan hasil perhitungan tersebut memberi gambaran bahwa introduksi teknologi tersebut layak secara finansial.

\section{DAFTAR PUSTAKA}

A, Husni Malian, 2004. Analisis Ekonomi Usahatani dan Kelayakan Finansial Teknologi pada Skala pengkajian. Pelatihan Analisis Finansial dan Ekonomi bagi Pengembangan Sistem Usahatani Agribisnis Wilayah, 29 Nopember - 9 Desember 2004.
Balitbangtan. 2011. Teknologi Budidaya Ubikayu Untuk Mencapai Produksi Optimal. Sinar Tani Edisi 29 Juni - 5 Juli 2011 No.3412 Tahun XLI. http://www.litbang.pertanian.go.id/dow nload/one/260/file/Teknologi-BudidayaUbikayu.pdf. Diakses 16 Januari 2017.

Bahri S dan Santoso, SJ. 2013. Perbanyakan tanaman ubi kayu (manihot esculenta crantz) dengan jumlah mata tunas pada varietas unggul mekar manik dan lokal. Volume XXV No. 2 Februari Tahun 2013.http://download.portalgaruda.org/a rticle.php?article $=142210 \& v a l=5266$ Diakses 16 Januari 2016

Dinas Pertanian dan Hortikultura Kabupaten Gunungkidul, 2015. Koordinasi dan Komunikasi Pribadi. Rabu tanggal 7 Januari 2014.

Dirjentan. 2014. Ubi kayu pangan alternatif potensial Kabupaten Pati. http://tanamanpangan.pertanian.go.id/be rita-ubi-kayu-pangan-alternatifpotensial-kabupaten-pati.html. Diakses 9 Januari 2015.

Dirjentan. 2013. Pedoman Teknis Pengelolaan Produksi Ubi Kayu Tahun 2012. Direktorat Budidaya Aneka Kacang dan Umbi. Direktorat Jenderal Tanaman Pangan. Kementerian Pertanian. 98 Hal. Dirjentan. 2014. Keputusan Menteri Pertanian Nomor 511 Tahun 2006 tanggal 12 September 2006 tentang Jenis Komoditi Tanaman Binaan Direktorat Jenderal Perkebunan, Direktorat Jenderal Tanaman Pangan dan Direktorat Jenderal Hortikultura. http://tanamanpangan. pertanian.go.id/hal-kepmentan.html.

Neltriana, N. 2015. Pengaruh dosis pupuk kandang kotoran sapi terhadap pertumbuhan dan hasil ubi jalar (ipomea batatas 1.). http://scholar. unand.ac.id/2352/1/620.pdf . Diakses 16 Januari 2017. 
Fitriani, dkk. 2015. Evaluasi stabilitas daya hasil ubi kayu (Manihot esculenta) genotip lokal hasil kultur jaringan. PROS SEM NAS MASY BIODIV INDON Volume 1, Nomor 8, Desember 2015 Halaman: 1756-1760. ISSN: 24078050 DOI:10.13057/psnmbi/m010802. http://biodiversitas.mipa.uns.ac.id /M/M0108/M010802.pdf . Diakses 16 Januari 2017.

Ispandi, A. 2003. Pemupukan $\mathrm{p}, \mathrm{k}$ dan waktu pemberian pupuk $\mathrm{k}$ pada tanaman ubikayu di lahan kering vertisol. Ilmu Pertanian Vol. 10 No. 2, 2003 : 35-50. http://agrisci.ugm. ac.id/vol10_2/5 _ispand_ubikayu.pdf. Diakses 16 Januari 2017.

Rahman N, dkk. 2015. Seleksi ubi kayu berdasarkan perbedaan waktu panen dan inisiasi kultur in vitro. PROS SEM NAS MASY BIODIV INDON Volume 1, Nomor 8, Desember 2015 Halaman: 1761-1765 ISSN: 2407-8050 DOI: 10.13057/ psnmbi/m010803. http:// biodiversitas.mipa.uns.ac.id/M/M0108/ M010803.pdf. Diakses 16 Januari 2017.
Widiyastiningsih., Sakhidin dan Supartoto. 2012. Respon beberapa varietas tomat (Lycopersicum esculentum Mill) terhadap pemberian mikoriza dan EM4. Journal of Inovation and Technology of Agroindustry Vol 1, No 1 (2012): volume 1 issue 1 (2012) . http://download. portalgaruda. org/article.php?art icle $=10447 \&$ val $=695 \&$ title $=$ RESPON $\%$ 20BEBERAPA\%20VARIETAS\%20TO MAT\%20(Lycopersicum\%20esculentu m\%20Mill)\%20TERHADAP\%20PEM BERIAN\%20MIKORIZA\%20DAN\%2 0EM4. Diakses 16 Januari 2017.

Wijanarko. A, A. Taufiq dan A.A. Rahmianna. 2011. Pengaturan Jarak Tanam Ubikayu dan Kacang Tanah untuk Meningkatkan Indeks Pertanaman di Lahan Kering Masam Banjarnegara. http://balitkabi. litbang.pertanian.go.id/info-teknologi/ 218-pengaturan-jarak-tanam-ubikayudan-kacang-tanah.html .Diakses tanggal 20 November 2015 pukul 12.30 wib. 